\title{
A study on relationship between dividend changes with future profitability
}

\author{
Hassan Ghodrati and Abbas Hashemi*
}

Department of Management and Accounting, Kashan Branch, Kashan, Iran

\section{CHRON I C L E A B S TRACT}

Article history:

Received July 28, 2013

Accepted 14 January 2014

Available online

March 82014

Keywords:

Profitability

Dividends changes

Profit growth

\begin{abstract}
This paper studies the relationship between dividend changes and future profitability of listed companies in Tehran Stock Exchange. Using the information of 191 companies, the study has implemented some regression techniques. The results of the research model analysis indicate that the changes in dividend contain significant and important information content, for the future profitability and dividend changes, and have an important and positive impact on the future profitability of the company. The results also show that changes in dividend can improve the company's future performances and messages to recovery the activities and future performance of the company. However, the results have shown the greatest impact on the performance of the dividend changes, for a year after considered year and not for two years after. In other words, the information content of dividend changes are more about the performance of the next year and the information provided is lower in the next two years.
\end{abstract}

C) 2014 Growing Science Ltd. All rights reserved.

\section{Introduction}

The increasing development and complexity of economic activities, the creation of various business units, the formation of independent legal entities and urgency in providing detailed information lead to the invention of different techniques in company evaluation. Simultaneously with development of accountancy, these methods and techniques have developed and provided to financial analysts and determiners. In the way of this development, the main role of researchers is clear to everyone. Researchers' efforts along with the need of users for better and more scientific information have caused accountancy to go a step further of its traditional role in reporting the financial events and activities. In addition, investors and stakeholders of companies have always paid special attention to information published by them so that the major financial information published by financial statements and considered. Many researchers and market participants believe that the changes in divined or dividend policy have informational value about the company's profitability. Therefore, it seems dividend and its changes have informational value about the company profitability.

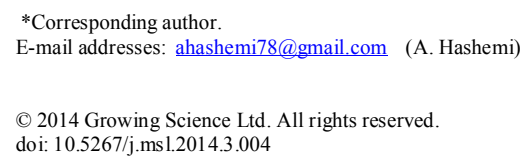


Miller and Rock (1985) are believed the first who reported that an informationally consistent signalling equilibrium existed under asymmetric information and the trading of shares. This restores the time consistency of investment policy, but leads in general to lower levels of investment than the optimum achievable under full information and/or no trading. Nissim and Ziv (2001) investigated the relationship between dividend changes and future profitability, measured in terms of either future earnings or future abnormal earnings. They reported that dividend changes could provide information about the level of profitability in subsequent years, incremental to market and accounting data. They also documented that dividend changes were positively associated with earnings changes in each of the two years after the dividend change. According to Grullon et al. (2002), firms that increase (decrease) dividends may experience a substantial decline (increase) in their systematic risk. The dividend-increasing firms did not increase their capital expenses and could experience a decline in profitability in the years after the dividend change.

Grullon et al. (2005) reported that, after controlling for the well-known nonlinear patterns in the behavior of earnings, dividend changes provided no information about future earnings changes. They also explained that dividend changes were negatively associated with future changes in profitability. In addition, they studied whether including dividend changes could improve out-of-sample earnings forecasts or not and reported that models that include dividend changes would not outperform those that had not included dividend changes. Li and Lie (2006) reported that the decision to change the dividend and the magnitude of the change could depend on the premium that the capital market places on dividends. They also reported that the stock market reaction to dividend changes may depend on the dividend premium. Therefore, the capital market may reward some managers for considering investor demand for dividends when making decisions about the level of dividends. Karpavičius (2014) provided other evidences on that firm value depends on payout policy. Kuo and Lee (2013) investigated the effects of dividend tax and signaling on firm valuation by looking into evidence from taxable stock dividend announcements.

\section{The proposed study}

The main hypothesis: the dividend changes and future profitability of the companies are related.

\section{Sub-hypotheses:}

1 - There is a relationship between dividend changes and future profitability of the companies.

2-There is a difference between the information content of dividend changes in the companies with high growth compared with firms with low growth.

3 -There is a relationship between the increasing and decreasing changes for information content of dividend.

Because of reliance on a theoretical basis and literature, general method or research type is In order to investigate the exchange company's issues and has a practical purpose. Because of using the random samples, inference methods has been used. Finally, due to use of historical performance data, the research project is Expose-Facto. In this study, the statistical population is the companies in Tehran Stock Exchange, which are not investment firms or financial intermediation in terms of activity. Among them 191 companies has been selected as the statistical sample based on the Cochrane formula and stratified random sampling. The performance of these companies has been studied over the period 2010-2012. In this study, we use the model of Choi et al. (2011), for an overall assessment in the impact of changes in the dividend on the future profitability, which is as follows,

$$
\left(E_{t}-E_{t-1}\right) / B_{-1}=\alpha_{0}+\alpha_{1} \% \Delta D i v_{i 0}+\alpha_{2} R O E_{i t-1}+\varepsilon_{i t}
$$

where $E_{t}$ is the ex-profit of extraordinary items, $B_{-1}$ is the book value of equity in the previous year. $\% \Delta D i v_{i 0}$ is the percentage of changes in dividends in this year against last year? In addition, 
$R O E_{i t-1}$ is the equity yield in the previous year and in this model we considered one year as Zero Year (0). In addition, after calculating the percentage of change in dividends for the year, we evaluate and analyze the relationship between the percentage and changes in the profitability for $(0+1)$ as well as $(0+2)$ years. In other words, if we consider the year 2001 as the zero year, the percentage of change in dividend is equal to :Div $\left.v_{2001}-D i v_{2000}\right) / D i v_{2000}$ and the dependent variable is equal to $\left(\left(E_{2001^{-}}\right.\right.$ $\left.\left.E_{2000}\right) / B_{2000}\right)$ for $\mathrm{t}=0$. Similarly, for the year (2002) with $\mathrm{t}=1$ and the year (2003) with $\mathrm{t}=2$, is equal to: ( $\left.\left(E_{2002}-E_{2001}\right) / B_{2001}\right)$. In other words, we compare and evaluate the impact of changes in the dividend for one year, on changes in profitability for two years after it.

Financial performance of 191 companies which was selected randomly among Iranian exchange companies, studied over the period 2010-2012. First, we described the dataset using descriptive statistical methods, and then investigated the basic assumptions in using of parametric statistical methods, and finally the relationship between variables was evaluated.

\subsection{Descriptive findings}

We describe the findings in the statistical sample by computing the basic statistical parameters including mean, median, variance, standard deviation stretching Coefficients. The calculations Results are summarized in Table 1:

\section{Table 1}

The summarizes of Variable Description results

\begin{tabular}{cccccc}
\hline Variable & mean & median & St. deviation & skewedness & kurtosis \\
\hline Dividend & .74004 & .8000 & 3.452247 & 9.243 & 112.565 \\
ROE t & .52320 & .40900 & .453462 & 2.784 & 12.592 \\
ROE t-1 & .58264 & .45500 & .475354 & 2.523 & 9.960 \\
ROE t-2 & .62547 & .50700 & .493871 & 2.962 & 16.217 \\
BM & .6960 & .7070 & .29091 & .844 & 6.651 \\
E0 & .0320 & .0150 & .11469 & 3.204 & 23.478 \\
E1 & .0287 & .0110 & .15072 & 3.334 & 29.653 \\
E2 & .0308 & .0160 & .20970 & 1.647 & 46.126 \\
ROA & .1644 & .1350 & .11789 & 1.019 & .786 \\
ROAT-1 & .1796 & .1570 & .12004 & .900 & .518 \\
\hline
\end{tabular}

Based on the values in Table 1, the Average of percentage change in dividends is $74 \%$, compared with the previous period. This amount reflects the fact that the sample companies have tried to pay higher dividends to their shareholders with respect to the previous period. The average rate of Assets yield (ROA) and Rate of return on equity (ROE) are $16 \%$ and $52 \%$, respectively, and given the fact that these values are not significantly different than their median, (13\% and $40 \%$, respectively), the variable distribution is relatively symmetric. The average of variable E represents the ratio of changes in ex-profit of extraordinary items against the book value of equity at beginning of period, and it was about 3\% during different years. Given the closeness of this value to the median value, (about 5.1 percent), it represents asymmetry in the variable distribution.

\subsection{Normality test}

Appropriate evaluation models have been made based on the assessment of errors distribution. Figs. 1 - 3 show the errors distribution or the difference between the estimated and actual values in each of the three models. Based on these figures the errors distribution is very close to a normal distribution. In addition, mean and standard deviation of these variables are very close to the normal distribution. ( 0 and 1 , respectively).so we can use the linear regression to analysis the dataset: 


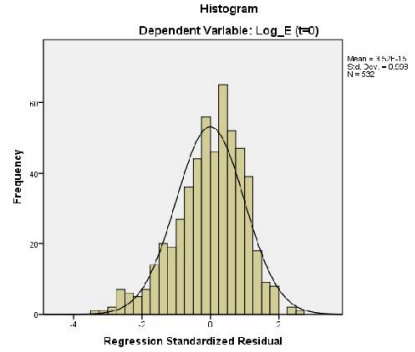

Fig. 1. Errors distribution of the first model

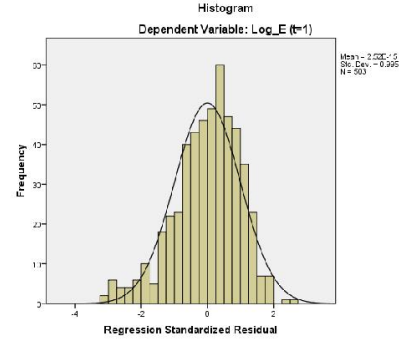

Fig. 2. Errors distribution of the second model

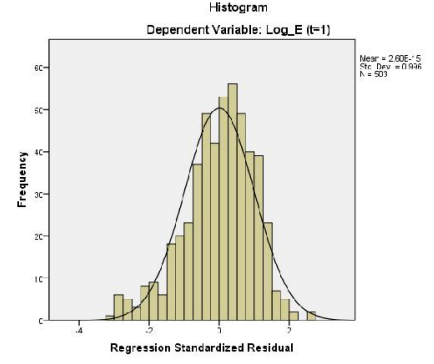

Fig. 3. Errors distribution of the third model

\section{The results}

\subsection{Analyzing the relationship between dividends and future profitability}

The combined linear regression was used in order to analyze the relationship between dividends and future profitability. This evaluation was accomplished for the first hypothesis of the study and based on three regression models for each year. In order to determine this relationship, the following model and cross-sectional regression is used according to this equation:

$\left(E_{t}-E_{t-1}\right) / B_{-1}=\alpha_{0}+\alpha_{1} \% \Delta D i v_{i 0}+\alpha_{2} R O E_{i t-1}+\varepsilon_{i t}$

Table 2 summarizes the estimation results of the linear regression relationship between variables:

Table 2

The assessment of the relationship between dividend changes and future profitability

\begin{tabular}{cccccc}
\hline Year & $\mathrm{R}$ & R SQUARE & ADJUSTED R S & ST.ERROR & D.WATSON \\
\hline $\mathrm{T}=0$ & 0.296 & 0.88 & 0.84 & 0.54546 & 1.836 \\
$\mathrm{~T}=1$ & 0.317 & 0.047 & 0.043 & 0.57708 & 1.868 \\
$\mathrm{~T}=2$ & 0.334 & 0.055 & 0.051 & 0.55314 & 1.876 \\
\hline
\end{tabular}

In addition, the Fisher test results are given in Table 3, in order to extended outcomes from each of the models in Table 2:

Table 3

The results of F-value

\begin{tabular}{cccccc}
\hline Year & Sum of Square & Degree of Freedom & Mean Square & F & Sig \\
\hline $\mathrm{T}=0$ & 15.123 & 2 & 7.562 & .298 .415 & .000 \\
& 157.391 & 529 & & & \\
$\mathrm{~T}=1$ & 172.514 & 531 & 4.120 & 12.373 & .000 \\
& 8.241 & 2 & .333 & & .000 \\
$\mathrm{~T}=2$ & 166.509 & 500 & & & \\
& 174.750 & 502 & 2 & .333 & \\
& 7.241 & 500 & & & \\
\end{tabular}

Note that the dependent variable in three consecutive years is:

$\mathrm{T}=0$ for considered Year

$\mathrm{T}=1$ for a year after considered Year

$\mathrm{T}=2$ for two years after considered Year 
This variable has been analyzed, in other words, the first research hypothesis has been examined for three consecutive years. According to the results of Table 2 and Table 3, the model determination coefficient, in $\mathrm{t}=0$ is equal to 0.088 , in $\mathrm{t}=1$ is equal to 0.047 and in $\mathrm{t}=2$ is also equal to 0.055 . The obtained determination coefficient, indicate the percentage of the dependent variable change which explained by the independent variables. Statistical value of $F$ in models are 24.415, 12.373 and 14.475, respectively, in years $(\mathrm{t}=2, \mathrm{t}=1, \mathrm{t}=0)$.

Given that meaningful area of the three models (in all three years), is equal to 0.000 , and since this amount is less than 0.05, Assuming that the coefficients of the independent variables is zero, the null hypothesis will be rejected at the $95 \%$ of confidence. This means that there is a linear relationship between the independent and dependent variables, in other words, the models are meaningful and the research hypothesis can be examined and tested using the regression model.

Table 4

The summarizes of estimating different parameters

\begin{tabular}{|c|c|c|c|c|c|c|c|}
\hline Year & Parameter & Coefficient & St. & Adjusted & T-Student & Sig. & VIF \\
\hline \multirow[t]{3}{*}{$\mathrm{T}=0$} & Constant & -1.444 & .041 & & -34.816 & .000 & \\
\hline & Dividend & .013 & .007 & .077 & 1.741 & .082 & 1.021 \\
\hline & ROET & .282 & .053 & .232 & 5.289 & .000 & 1.021 \\
\hline \multirow[t]{3}{*}{$\mathrm{T}=1$} & Constant & -1.614 & .038 & & -42.251 & .000 & \\
\hline & Dividend & .014 & .006 & .103 & 2.449 & .015 & 1.025 \\
\hline & ROET & .336 & .048 & .294 & 6.995 & .000 & 1.025 \\
\hline \multirow[t]{3}{*}{$\mathrm{T}=2$} & Constant & -1.534 & .043 & & -35.591 & .000 & \\
\hline & Dividend & .010 & .007 & .097 & 1.980 & .048 & 1.024 \\
\hline & ROET & .283 & .058 & .217 & 4.914 & .000 & 1.024 \\
\hline
\end{tabular}

According to Table 4, the amount of t-statistic and the meaningful area for the variable of changes in corporate dividend, (\%Div.), is 2.449 with Sig. $=0.015$ at $\mathrm{T}=0$. It represents the significant and positive impact of this variable on changes in corporate profitability (the ex-profit of extraordinary Items). The amount of t-statistic and the meaningful area for the variable of changes in corporate dividend, $(\% \mathrm{Div}$.$) , is 1.980$ with Sig. $=0.048$, respectively at $\mathrm{T}=1)$. It represents the important and positive impact of this variable, on changes in corporate profitability (with the $95 \%$ of confidence level). The amount of t-statistic and the meaningful area for the variable of changes in corporate dividend, (\%Div.), is 1.741 with $\mathrm{Sig}$. $=0.082$, respectively at $\mathrm{T}=2)$. It means that although this variable maintains a positive impact on future profitability but this impact was not statistically significant at the $95 \%$ confidence level. Nevertheless, this impact is quite meaningful and significance at the $90 \%$ confidence level.

According to the results as described above, we can say that the change in dividend had a significant impact on future profitability. The obtained outcomes could be considered from this dimension that the changes (incremental changes) in the dividend can reflect the positive signs for a growing trend of operations and financial condition of the company. Therefore, the first research hypothesis is approved at the confidence level of $95 \%$, based on the changes of the dividend has information content, and maintains an impact on the company's future profitability.

\subsection{A comparison between the companies}

The next analysis is about the comparison of changes in corporate profits based on the rate of growth, and it has been carried out to test the second hypothesis. To perform this comparison, firms are divided into groups with the low growth $(\mathrm{M} / \mathrm{B}<0.5)$ and high growth $(\mathrm{M} / \mathrm{B}>0.5)$. To assess differences between the profit changes in groups, we used the separate regression assessment for each group. The results of this evaluation are summarized in Table 5 as follows, 
Table 5

Comparison between companies based on their growth

\begin{tabular}{|c|c|c|c|c|c|c|c|}
\hline Group & Parameter & Beta & St. & Adjusted & $\mathrm{T}$ & Sig. & VIF \\
\hline \multirow{6}{*}{$\mathrm{B} / \mathrm{M}<0.5$} & CONSTANT & -1.218 & .101 & & -12.107 & .000 & \\
\hline & DIV\% & .023 & .034 & .059 & .668 & .505 & 1.249 \\
\hline & ROET-1 & -.051 & .108 & -.053 & -.475 & .636 & 1.953 \\
\hline & DIV T-1 & .018 & .014 & .103 & 1.223 & .223 & 1.135 \\
\hline & ROE T-2 & .139 & .114 & .140 & 1.223 & .223 & 2.081 \\
\hline & $\mathrm{E}(\mathrm{T}=0)$ & .580 & .265 & .192 & 2.190 & .030 & 1.233 \\
\hline \multirow{6}{*}{$\mathrm{B} / \mathrm{M}>0.5$} & CONSTANT & -1.623 & .061 & & -26.645 & .000 & \\
\hline & DIV\% & .005 & .007 & .037 & .667 & .505 & 1.092 \\
\hline & ROET-1 & .077 & .124 & .041 & .619 & .536 & 1.514 \\
\hline & DIV T-1 & .006 & .008 & .038 & .694 & .488 & 1.045 \\
\hline & ROE T-2 & .141 & .108 & .087 & 1.308 & .192 & 1.542 \\
\hline & $\mathrm{E}(\mathrm{T}=0)$ & 1.276 & .483 & .147 & 2.642 & .009 & 1.085 \\
\hline
\end{tabular}

The $\mathrm{t}$-value for low growth and high growth for dividend are (t-value $=0.668$, Sig. $=0.505)$ and $(\mathrm{t}-$ value $=0.667$, Sig. $=0.505)$, respectively. This indicates that this variable has a positive impact on future profitability, but this impact was not statistically significant (changes in ex-profit of Extraordinary Items). Moreover, t-statistic values in both low-growth $(\mathrm{B} / \mathrm{M}<0.5)$ and high growth firms $(B / M>0.5)$ did not differ much from each other. Given these results, we can say that the second research hypothesis is rejected at the 95\% significance level, Based on, the information content of dividend changes are different in companies with high growth compared with the firms with low growth. The linear test results shows that the VIF-statistic values in the variables of research models, are close to 1 . Given that values below 10 indicate a lack of linear-dependency among the independent variables, we can say there is no problem of linear-dependency between independent variables. The obtained determination coefficient for the low-growth firms $(\mathrm{B} / \mathrm{M}<0.5)$ and high growth firms (B / M > 0.5), are 0.057 and 0.029, respectively, and the amount is relatively low. Watson camera statistic, in both research models is close to 2 , these values indicate lack of residual correlation. The value of F-statistic in research model for the low-growth firms $(\mathrm{B} / \mathrm{M}<0.5)$ and high growth firms (B / $\mathrm{M}>0.5$ ) are not significant at the 95\% confidence level for both low-growth and high growth firms (It is meaningful at $90 \%$ confidence level).

\subsection{The relationship between information content of companies and dividends}

In this regard, the following regression equation is used:

$\left(E_{t}-E_{t-1}\right) / B_{-1}=\alpha_{0}+\alpha_{1} D P C\left(\% \Delta D i v_{0}\right)+\alpha_{2} D N C\left(\% \Delta D i v_{0}\right)+\alpha_{3} R O E_{t-1}++\propto_{4}\left(E_{0}-E_{-1}\right) / B_{-1}+\varepsilon_{t}$

Similarly, Table 6 shows details of our findings on relationship between the information content of dividend.

Table 6

Relationship between the information content of dividend

\begin{tabular}{|c|c|c|c|c|c|c|c|}
\hline Group & Parameter & Beta & St. & Adjusted & $\mathrm{T}$ & Sig. & VIF \\
\hline \multirow{5}{*}{$\mathrm{T}=1$} & CONSTANT & -1.526 & .047 & & -32.753 & .000 & \\
\hline & DIV\% & .006 & .007 & .138 & 3.863 & .000 & 1.062 \\
\hline & ROET-1 & 1.43 & .098 & .066 & 1.462 & .144 & 1.123 \\
\hline & DIV T-1 & .243 & .056 & 0.187 & 4.323 & .000 & 1.042 \\
\hline & $\begin{array}{c}\text { ROE T-2 } \\
E(T=0)\end{array}$ & 1.102 & .221 & .224 & 4.987 & .000 & 1.123 \\
\hline \multirow[b]{5}{*}{$\mathrm{T}=2$} & CONSTANT & -1.44 & .047 & & -30943 & .000 & \\
\hline & DIV\% & .011 & .008 & .163 & 3.422 & .000 & 1.083 \\
\hline & ROET-1 & .015 & .103 & .007 & .147 & .883 & 1.213 \\
\hline & DIV T-1 & .262 & .054 &. .216 & 4.880 & .000 & 1.045 \\
\hline & $\begin{array}{l}\text { ROE T-2 } \\
\text { E }(\mathrm{T}=0)\end{array}$ & .752 & .284 & .127 & 2.644 & .008 & 1.242 \\
\hline
\end{tabular}


According to Table 6, the regression estimates provided for mentioned years. In addition, other calculations show that the determination coefficient of model for $\mathrm{t}=1$ is equal to 0.107 and for $\mathrm{t}=2$ is also equal to 0.070 . The obtained determination coefficient indicates the percentage of the dependent variable change, which explained by the independent variables. Watson camera statistic in both models is close to 1.9 , which indicates that the model did not suffer from autocorrelation. Therefore, one of the assumptions of regression has been approved.

T-statistics and significance level for variables of positive changes in the dividend, (DPC*\%Div), indicates positive and significant impact of this variable on future profitability of the company in both models. T-statistics and significance level for variables of negative changes in the dividend, (DNC *\% Div.), indicates positive but meaninglessness impact on future profitability, which indicates the low information content of the variable. In general, it can be said that the information content of incremental changes in dividend is different with the decreasing changes types.

\subsection{Analysis of the interaction of variables}

In order to assess mutual influences of variables on each other, Pearson correlation analysis was used. The results of this analysis have been summarized in Table 7. In this table interaction of variables have been determined separately, for each of the years (Zero, one and two).

Table 7

Analysis of interaction of variables

\begin{tabular}{|c|c|c|c|c|c|c|}
\hline Variable & LOG E $(\mathrm{T}=0)$ & LOG E $(\mathrm{T}=1)$ & LOG E(T=2) & \%DIV & ROE T-1 & ROA T-1 \\
\hline \multirow[t]{3}{*}{$\log -\mathrm{E}(\mathrm{T}=0)$} & 1 & .377 & .332 & .157 & .278 & .329 \\
\hline & & .000 & .000 & .007 & .007 & .000 \\
\hline & 532 & 330 & 313 & 532 & 532 & 532 \\
\hline \multirow[t]{3}{*}{$\log -\mathrm{E}(\mathrm{T}=0)$} & .377 & 1 & .419 & .134 & .207 & .268 \\
\hline & .000 & & .000 & .049 & .000 & .000 \\
\hline & 330 & 503 & 315 & 503 & 503 & 503 \\
\hline \multirow[t]{3}{*}{$\log -\mathrm{E}(\mathrm{T}=0)$} & .332 & .419 & 1 & .043 & .221 & .275 \\
\hline & .000 & .000 & & .337 & .000 & .000 \\
\hline & 313 & .315 & 503 & 503 & 503 & 503 \\
\hline \multirow[t]{3}{*}{ DIV\% } & .157 & .134 & .043 & 1 & -.127 & -.149 \\
\hline & .007 & .049 & .337 & & .000 & .000 \\
\hline & 532 & 503 & 503 & 847 & 847 & 847 \\
\hline \multirow[t]{3}{*}{ ROET-1 } & .278 & .207 & .221 & -.127 & 1 & .719 \\
\hline & .000 & .000 & .000 & .000 & & .000 \\
\hline & 532 & 503 & 503 & 847 & 847 & 847 \\
\hline \multirow[t]{3}{*}{ ROA T-1 } & .329 & .268 & .275 & -.149 & .719 & 1 \\
\hline & .000 & .000 & .000 & .000 & .000 & \\
\hline & .532 & .503 & .503 & .847 & .847 & 847 \\
\hline
\end{tabular}

The correlation coefficient between changes in dividends and changes in corporate profitability is 0.157 (year 0 ) with significance level of 0.007 , indicating a positive and significant relationship between the two variables. There is a significant and positive relationship between the changes in dividend and changes in company profitability. Note that the correlation coefficient between two variables is 0.134 and the significance level is 0.049 . The correlation coefficient between dividend changes and the changes in company profitability, $(\mathrm{t}=2)$, is equal to 0.043 , which shows a positive relationship between these two variables. This positive relationship is not considered significant. There is a positive and significant relationship between the equity returns and asset returns with changes in company profitability.

\section{Conclusion}

The results of the research model analysis indicate that the changes in dividend contain significant and important information content, for the future profitability and dividend changes, and have an 
important and positive impact on the future profitability of the company. The results also show that changes in dividend can improve the company's future performances and messages to recovery the activities and future performance of the company. However, the results have shown the greatest impact on the performance of the dividend changes, for a year after considered year and not for two years after. In other words, the information content of dividend changes are more about the performance of the next year and the information provided is lower in the next two years. Other results have indicated that incremental changes in dividends contain more information, compared with decreasing changes, and investors and shareholders paid more attention to the incremental changes in dividends.

The impact of incremental changes in dividend in the future performances is positive and significant, while the impact of decreasing dividend changes on future profitability is not very meaningful. Other results of the study have also indicated that the type and severity of impact on dividend changes and future profitability was not affected by the company growth, and finally, the information content of dividend changes among firms with high growth and lower growth, was not considerably different.

\section{Acknowledgement}

The authors would like to thank the anonymous referees for constructive comments on earlier version of this paper.

\section{References}

Choi, Y. M., Joo, H. K., \& Park, Y. K. (2011). Do dividend changes predict the future profitability of firms?. Accounting \& Finance, 51(4), 869-891.

Grullon, G., Michaely, R., \& Swaminathan, B. (2002). Are dividend changes a sign of firm maturity?. The Journal of Business, 75(3), 387-424.

Grullon, G., Michaely, R., Benartzi, S., \& Thaler, R. H. (2005). Dividend changes do not signal changes in future profitability. The Journal of Business, 78(5), 1659-1682.

Karpavičius, S. (2014). Dividends: Relevance, rigidity, and signaling. Journal of Corporate Finance, 25, 289-312.

Kuo, N.T., \& Lee, C.F. (2013). Effects of dividend tax and signaling on firm valuation: Evidence from taxable stock dividend announcements. Pacific-Basin Finance Journal, 25, 157-180

Li, W., \& Lie, E. (2006). Dividend changes and catering incentives. Journal of Financial Economics, 80(2), 293-308.

Miller, M. H., \& Rock, K. (1985). Dividend policy under asymmetric information. The Journal of Finance, 40(4), 1031-1051.

Nissim, D., \& Ziv, A. (2001). Dividend changes and future profitability. The Journal of Finance, 56(6), 2111-2133. 